\title{
Plasmid vector based generation of transgenic mesenchymal stem cells with stable expression of reporter gene in caprine
}

\author{
Manish Kumar ${ }^{1}$, Renu Singh ${ }^{1}$, Kuldeep Kumar ${ }^{1}$, Pranjali Agarwal ${ }^{1}$, \\ Puspendra Saswat Mahapatra ${ }^{1}$, Abhisek Kumar Saxena ${ }^{2}$, Ajay Kumar $^{3}$, \\ ${ }^{1}$ Division of Physiology and Climatolxcogy, Indian Veterinary Research Institute, Bareilly, India; \\ *Corresponding Author: bag658@gmail.com \\ ${ }^{2}$ Division of Surgery, Indian Veterinary Research Institute, Bareilly, India \\ ${ }^{3}$ Division of Biochemistry, Indian Veterinary Research Institute, Bareilly, India \\ ${ }^{4}$ Central Avian research Institute, Bareilly, India \\ ${ }^{5}$ Animal Biotechnology Center, National Dairy Research Institute, Karnal, India \\ ${ }^{6}$ Division of Pathology, Indian Veterinary Research Institute, Bareilly, India
} Subrata Kumar Bhanja ${ }^{4}$, Dhruba Malakar ${ }^{5}$, Rajendra Singh ${ }^{6}$, Bikas C. Das $^{1}$, Sadhan $_{\text {Bag }^{1 *}}$

Received 30 August 2013; revised 26 September 2013; accepted 4 October 2013

Copyright (C) 2013 Manish Kumar et al. This is an open access article distributed under the Creative Commons Attribution License, which permits unrestricted use, distribution, and reproduction in any medium, provided the original work is properly cited.

\section{ABSTRACT}

The production of cells capable of expressing gene(s) of interest is important for a variety of applications in biomedicine and biotechnology, including gene therapy and a novel method of stem cell therapy in the various diseases. Achieving high levels of transgene expression for the longer period of time, without adversely affecting cell viability and differentiation capacity of the cells, is crucial. In the present study, we investigated the efficiency of plasmid vector for the production of transgenic cMSCs and examined any functional change of cells after transfection. To do so first we have collected bone marrows from the adult goats and cultured them for isolation of mesenchymal stem cells (cBM-MSCs). These cells were characterized using MSC specific markers including differentiation into osteocytes and adipocytes. Transfection with plasmid vector did not adversely affect cBM-MSCs morphology, viability or differentiation potential, and transgene expression levels were unaffected beyond passage 12th. The results indicated that we have been able to generate transgenic caprine MSC (tcBM-MSC) and transfection of CBM-MSCs using plasmid vector resulted in very high and stable transfection efficiency. This finding may have considerable significance in improving the efficacy of MSCbased therapies and their tracking in animal model.

Keywords: Transgenic MSC; Caprine; Plasmid Vector; Characterisation; In Vitro Differentiation

\section{INTRODUCTION}

Mesenchymal stem cells (MSCs) are multipotent, selfrenewing cell population isolated from different sources especially from bone marrow and look extremely promising due to their potential to differentiation into cells of different lineages including chondrocytes, osteoblasts and adipocytes [1], their trans-differentiation potentiality to form connective tissue like, muscle, heart, blood vessels and nerves etc. [2-4], their ability to home to sites of injury after systemic delivery $[5,6]$ and their evasion of normal host immune responses [7], easy to isolate from almost all individuals as well as their ability not to form teratomas [8]. These cells are currently being used for transplantation into various diseases viz improvement to myocardial and cerebral function (after cerebral infarction), repair of liver damage [9], bone fracture [10], healing of wound $[11,12]$, repair of damaged ligaments and joint damage $[13,14]$, repair of spinal cord injury $[15,16]$ etc.

So far most of the applications of MSC have been studied in laboratory animal with an aim of their application in human being. However, recently MSC of domestic animals are being studied in-depth and in near future these cells would be used for therapeutics in divergent 
areas of diseases as well as a vehicle for gene delivery. However, to understand their regenerative potentiality, thorough transplantation studies should be undertaken. But one of the challenges lies in tracking stem cells following in vivo transplantation to understand the fate of the transplanted cells.

While there are many ways to label and track cells, but the transgenic MSC expressing green fluorescent protein (GFP) has been found efficient because it can be detected with high sensitivity and specificity, combined with its relative ease of insertion, expression, and detection [17]. Currently many methods are available to produce transgenic cells for the functional studies of genes, drug discovery and gene therapy. But attempts have been made to generate transgenic MSC with reporter gene in different species using viral and non viral based vectors [18] with varying success. In most of the studies it has been reported that plasmid vector is very less efficient [18] and stable transgenic MSC could not be generated. However, comparatively stable transgenic MSC [19] has been generated using viral based transgenesis particularly lentivirus in different species including human beings [2023].

So far very less attempts have been made to generate stable transgenic MSC in domestic animal [24]. Therefore, in the present study, an attempt was made to transfect bone marrow derived caprine MSC using a plasmid vector with reporter gene so that transgenic stem cells can be generated for their further use in transplantation studies.

\section{MATERIALS AND METHODS}

All the chemicals used in this study were procured from Sigma, unless indicated. The primary and secondary antibodies used for immunocytochemistry and FACS analysis were purchased from Santa Cruz Biotechnology, USA.

\subsection{Isolation and Expansion of CBM-MSCs}

The goats of around one year old of either sex were selected for bone marrow collection which were maintained in the Animal Shed of Physiology and Climatology Division, Indian Veterinary Research Institute, Izatnagar, India. The permission for institute ethical committee was taken for collection of bone marrow from caprine. The selected goat was anesthetized using standard protocol. The area of iliac crest (site of collection) on either side was prepared aseptically. The bone marrow aspirate was collected with the help of an $18 \mathrm{G}$ bone marrow biopsy needle from the lateral aspect of iliac crest. About $4-5 \mathrm{ml}$ bone marrow aspirate was drawn/ aspirated. Immediately after collection bone marrow aspirate brought to the laboratory and processed.
The marrow sample was diluted with equal amount of Dulbecco's phosphate buffered saline (DPBS, Invitrogen, \#cat. 14190-144) and slowly layered onto $10 \mathrm{ml}$ of Ficol-Hypaque (Sigma, \#cat. 1077). The sample was subjected to centrifuge at $2000 \mathrm{rpm}$ for $30 \mathrm{~min}$ and the nucleated cells were collected from the interface. The cells were washed with two volumes of DPBS and collected by centrifugation at $2000 \mathrm{rpm}$ for $10 \mathrm{~min}$. The cells were resuspended, counted and plated at $2 \times 10^{5}$ cells $/ \mathrm{cm}^{2}$ in $\mathrm{T}-25$ tissue culture flasks. The cells were maintained in culture medium with antibiotics (mixture of 100 units $/ \mathrm{ml}$ of penicillin and $100 \mu \mathrm{g} / \mathrm{ml}$ of streptomycin (Gibco \#cat. $15140-122)$ in incubator with atmosphere of $5 \% \mathrm{CO}_{2}$, $95 \%$ humidity at $37^{\circ} \mathrm{C}$ for 48 hours. The culture medium used for cell propagations was DMEM-low glucose (HyClone, \#cat. SH30021.01) + 15\% serum. After 48 hours of primary culture, the non adherent cells were removed by changing the medium. The medium was changed every third days thereafter. The confluent cells were propagated 1.3 ratios with trypsinisation method.

\subsection{Assessment of Cell Viability Using Probes for Membrane Integrity}

Approximately $10^{6} \mathrm{cBM}-\mathrm{MSCs}$ were suspended in 1 $\mathrm{ml}$ PBS in $15 \mathrm{ml}$ centrifuge tube and $2 \mu \mathrm{g}$ propidium iodide (PI) was added. After incubation on ice for $5 \mathrm{~min}$ in dark, the cells were analysed on flow cytometer with excitation at $488 \mathrm{~nm}$ and emission collected at $>550 \mathrm{~nm}$.

\subsection{Chromosome Analysis}

The chromosome analysis was done using conventional Giemsa staining method. In early growing (48 hr of seeding) cBM-MSCs, culture media was replaced by colcemid $(0.05 \mu \mathrm{g} / \mathrm{ml}$, PAA, \#cat. J01-003) containing media \& incubated for $15 \mathrm{hrs}$ at $37^{\circ} \mathrm{C}, 5 \% \mathrm{CO}_{2}$ in $\mathrm{CO}_{2}$ incubator. The cells were trypsinized and treated with $0.56 \% \mathrm{KCl}$ hypotonic solution for $30 \mathrm{~min}$. After this, cells pellet were treated with 3.1 methanol, acetic acid and slides were prepared using this. The slides were stained with Giemsa stain and observed under microscope at $100 \times$ in oil immersion.

\subsection{In Vitro Differentiation}

To induce adipogenic differentiation, normal and transgenic MSCs were cultured to near confluence and the complete media was replaced by adipogenic induction medium consisting of DMEM containing $+10 \%$ FBS (Gibco, \#cat. 16000-044) and antibiotics +100 nmol-Dexamethasone (Sigma, \#cat. D2915) + 50 mg/mlindomethacin (Sigma, \#cat.17378.) + $10 \mu \mathrm{g} / \mathrm{ml}$ - insulin (Sigma, \#cat.I6634). The induction medium was changed every 3 days. At the end of the differentiation period, cells were fixed with $4 \%$ paraformaldehyde for $10 \mathrm{~min}$ 
and lipid droplets were stained by Oil Red O (Sigma, \#cat.00625) staining.

To induce osteogenic differentiation, the confluent cBM-MSC were incubated in osteogenic induction medium consisting of DMEM medium containing $10 \%$ FBS, antibiotics, $10 \mathrm{nmol}$ Dexamethasone (Sigma \#cat. D2915), $10 \mathrm{mmol}$ glycerophosphate (Sigma \#cat. G9422), 0.3 $\mathrm{mM}-\mathrm{L}$ ascorbic acid (Sigma \#cat. A4403). The induction medium was changed every 3 days. The bone matrix mineralization was evaluated by Alizarin red S (Sigma \#cat. A5533) staining. The induced cells were also examined for alkaline phosphatase activity. For further confirmation of differentiation, RNA was isolated from differentiated cells and cDNA was synthesised from RNA for real time PCR analysis of osteogenic and adipogenic gene expression.

\subsection{Alkaline Phosphatase Staining}

The cBM-MSCs were in vitro differentiated cells were subjected to alkaline phosphatase staining. Cell monolayer was rinsed in DPBS, fixed in 4\% paraformaldehyde and then overlaid with AP stain, (Naphthol AS-MX Phosphate $(0.5 \mathrm{mg} / \mathrm{ml})$ and Fast Red TR salt $(1 \mathrm{mg} / \mathrm{ml})$ (Millipore, USA) mixed in $100 \mathrm{mM}$ Tris-HCl, $\mathrm{pH}-8.2$ ) for 4 hours at $37^{\circ} \mathrm{C}$, rinsed again with DPBS. Stained cells were observed under inverted light microscope (Olympus-1X51S8F3, Japan).

\subsection{Immunocytochemistry}

Normal as well as transgenic cBM-MSCs, cultured on cover slip in six well plate up to $70 \%-80 \%$ confluency were fixed using $4 \%$ paraformaldehyde in $1 \mathrm{X}$ PBS for 20 min and were washed thrice with $1 \times$ PBS at room temperature. The cells were incubated in permeabialization solution containing $0.3 \%$ Triton X-100 and $4 \%$ BSA in PBS $20 \mathrm{~min}$ for detection of intracellular markers. The cells were washed thrice with $1 \times$ PBS at room temperature. Non specific binding sites were blocked with $10 \%$ normal goat serum in PBS for $40 \mathrm{~min}$ at room temperature and the cells were washed thrice with 1X PBS. Cells were treated with primary antibodies from Santacruiz viz CD105 (\#sc-19793), CD90 (\#sc-9162) and CD73 (\#sc25603) (1200 dilution) for each markers for overnight at $4^{\circ} \mathrm{C}$ and washed thrice with $1 \times$ PBS. The cells were then incubated with respective secondary antibodies (1800 dilution) for one hour at room temperature and washed thrice with $1 \times$ PBS. The cells were counter stained with DAPI to stain the nucleus. The cells were examined under ZEISS fluorescent microscope. Mesenchymal stem cells were stained simultaneously without addition of primary antibody as control for each antibody.

\subsection{FACS Analysis}

FACS analysis was performed to investigate the ex- pression of MSCs specific transcriptional markers viz. CD-73 (\#sc-25603), CD-105 (\#sc-19793) as well as hematopoitic stem cells marker CD-45 (\#sc-25590) in cBM-MSCs. Cells were harvested and aliquoted at a density of $1.0 \times 10^{6}$ cells $/ \mathrm{ml}$ for each staining. The cell suspensions were incubated for $15 \mathrm{~min}$ at $4^{\circ} \mathrm{C}$ (on ice) with $10 \%$ normal goat serum in PBS to block nonspecific binding of the primary antibody. After washing the cells were incubated with primary antibodies against CD-73 and CD-105 overnight at a conc. of $2 \mu \mathrm{g} / \mathrm{ml}$ at $4^{\circ} \mathrm{C}$. After three DPBS washes, cells were incubated with FITC conjugated anti goat secondary antibody for $2 \mathrm{hr}$ at $4{ }^{\circ} \mathrm{C}$ in dark. Thereafter, the cells were fixed with 1\% PFA for $5 \mathrm{~min}$. Cells were washed thrice and analyzed using a flow cytometer (Becton Dickinson, San Jose, CA, USA) using a negative control processed in similar manner but without primary antibody. The data obtained was analyzed using Cell Quest program and plotted as single parameter histogram.

\subsection{In-Vitro Transdifferentiation of Mesenchymal Stem Cells into Neurons}

The normal and transgenic cBM-MSCs at passage four were induced to become neuronal-like cells under in vitro conditions as per given methods [25]. Briefly, subconfluent (approximately $80 \%-85 \%$ confluent) cultures of cBM-MSCs were maintained in DMEM $+20 \%$ FBS. Twenty-four hours prior to neuronal induction, media were replaced with pre-induction media consisting of DMEM $+20 \%$ FBS $+1 \mathrm{mM} \beta$-mercaptoethanol (BME) (Sigma \#cat. M7522). To initiate neuronal differentiation, the preinduction media were removed, and the cells were transferred to neuronal induction media composed of DMEM + 2 - $10 \mathrm{mM}$ BME. Cells were fixed for immunocytochemistry at times ranging from $24 \mathrm{hr}$ to 6 days post-induction. The cells were observed every $12 \mathrm{hr}$ for change in morphology. Differentiated cBM-MSCs were fixed in $4 \%$ paraformaldehyde and processed for immunostaining using neuron specific markers. Molecular characterizations of differentiated cells were also done to validate the neuronal differentiations.

\subsection{Real Time PCR}

For gene expression analysis, different passage of cBM-MSCs and ifferentiated cells were isolated by using Trypsin-EDTA and washed with 1X PBS. The cells were transferred in $2 \mathrm{ml}$ DNAase and RNAse free tube for RNA isolation. The total RNA was isolated using mini RNA kit as per manufacturer's protocol (Zymo Research, Cat No. R1005). The cDNA were synthesized from total RNA using cDNA synthesis kit (Biorad, Cat No. 170 8891) as per the manufacturer's instructions.

The gene expression of cBM-MSC and transdiferenti- 
ated cells were analysed by Real Time Polymerase Chain Reaction (Biorad) and Evagreen supermix (Biorad, Cat No. 172-5200), as a double stranded DNA-specific fluorescent dye. For real time amplification of genes, primers were designed in beacon software. The reaction mix was prepared in a volume of $10 \mu \mathrm{l}$ by mixing $3.0 \mu \mathrm{l}$ nuclease free water, $5.0 \mu \mathrm{l}$ Evagreen supermix, $0.5 \mu \mathrm{l}$ of forward and reverse primer each and $1.0 \mu \mathrm{l}$ of cDNA. The conditions for thermocycling were as follow, initial denaturation at $95^{\circ} \mathrm{C}$ for $30 \mathrm{sec}$ followed by 40 cycles (denaturation at $95^{\circ} \mathrm{C}$ for $3 \mathrm{sec}$, annealing for $10 \mathrm{sec}$ at specific temperature for each gene as mentioned in Table 1.

\subsection{Transfection of cBM-MSCs}

A total number of 50,000 cells were plated per well in a 12-well tissue culture plate. After 24 hours of culture, Lipofectamine-2000 mediated (LF2000) (1 mg/mL) (\#cat no. 31985-062, Invitrogen) transient transfection was performed according to the protocol given by the supplier (Invitrogen), varying transfection reagent volumes and the amount of DNA (pAcGFP1-C1, Cat No-632470, Clonotech, USA) were carried out in OPTIMEM1 (Gibco), without serum or antibiotics. In one well of 24 well tissue culture dish, first dilution of amplified plasmid DNA $(0.8-1.6 \mu \mathrm{g})$ in $100 \mu \mathrm{l}$ of Opti-MEM ${ }^{\circledR} \mathrm{I}$ (Cat. No. 31985, Gibco) was done followed by a gentle mixing. Appropriate amount of lipofectamine was mixed well in $100 \mu \mathrm{l}$ of Opti-MEM ${ }^{\circledR} I$ medium in another well and incubated for $5 \mathrm{~min}$ at room temperature. After the incubation, diluted plasmid DNA and Lipofectamine-2000 was mixed together (total volume now $200 \mu \mathrm{l}$ ) followed by further incubation for $25-30 \mathrm{~min}$ at room temperature to allow the DNA-Lipofectamine 2000 complexes to form. Before the transfection, culture medium of MSC was changed to serum and antibiotics free DMEM and washed with it (serum and antibiotic free DMEM medium) twice before addition of DNA and Lipofectamine complex. Once the plasmid DNA and lipofectamine complex was ready to use, $800 \mu \mathrm{l}$ fresh media was added to it and the total content was mixed gently by rocking the plate back and forth. The complex was added on the semi confluent cBM-MSCs and the cells were kept in $\mathrm{CO}_{2}$ incubator at $37^{\circ} \mathrm{C}$. The cells were observed under microscope and after six hours of transfection, the medium was replaced with fresh one ml DMEM supplemented with serum. Expression of GFP which indicated successful transfection was observed after $24 \mathrm{hr}$ of transfection under fluorescence microscope. After $72 \mathrm{hr}$ of transfection, the previous media was replaced by selection media containing neomycin (G418, sigma)@ $300 \mu \mathrm{g} / \mathrm{ml}$ which was continued at least for two weeks. Subsequently tcBM-MSC were passaged and propagated to increase the cell population and characterized to check for the MSC characteristics as that of the primary MSC culture.

\section{RESULTS}

\subsection{Growth and Culture Characteristics of cBM-MSCs}

Bone marrow was harvested from iliac crest of the goats and buffy coat was separated from the bone marrow and cells were plated into $25 \mathrm{~mm}$ culture flask at the density of $5 \times 10^{5}$ cells using DMEM culture media (Figure 1(A)). Non-adherent cells were carefully removed after 48 hours and fresh medium was replaced. Thereafter, this step was repeated every 24 hours for up to 96 hours of initial culture. Then, the adherent cells (passage $0)$ were washed with $1 \times$ Dulbecco's phosphate-buffer

Table 1. Primers and conditions used for gene specific real time PCR analysis.

\begin{tabular}{|c|c|c|c|c|c|}
\hline S. No & Target Gene & Primer sequence, 5'-3' & $\begin{array}{c}\text { Annealing } \\
\text { temperature }\left({ }^{\circ} \mathrm{C}\right)\end{array}$ & $\begin{array}{l}\text { Product } \\
\text { (bp) }\end{array}$ & $\begin{array}{l}\text { Reference sequence } \\
\text { accession no. }\end{array}$ \\
\hline 1. & GAPDH & $\begin{array}{l}\text { f 5'ggagaaacctgccaagtatg } 3 \text { ', } \\
\text { r 5'tgagtgtcgctgttgaagtc } 3 \text { ' }\end{array}$ & 65 & 126 & DQ152956.1 \\
\hline 2. & $\begin{array}{l}\text { THY1 } \\
(\text { CD90) }\end{array}$ & $\begin{array}{l}\text { f } 5 \text { 'cctcctgctaacagtcttac } 3^{\prime} \\
\text { r 5'atcettggtggtgaagttg3' }\end{array}$ & 60 & 271 & BC104530 \\
\hline 3. & $\begin{array}{c}\text { ENG } \\
(\mathrm{CD} 105)\end{array}$ & $\begin{array}{l}\text { f 5'agcgatggcatgactctg3', } \\
\text { r 5'aggetgtccgtgttgatg } 3 \text {, }\end{array}$ & 65 & 251 & NM_001076397 \\
\hline 4. & CD73 & $\begin{array}{l}\text { f 5'aacacacagtggtgctctcttcc3' } \\
\text { r 5'tgttgtcttgggtgtgtgtgcctaga3, }\end{array}$ & 60 & 401 & BC114093.1 \\
\hline 5 & ADIPSIN & $\begin{array}{l}\text { f 5'-caccatcactgagcgaatga-3' } \\
\text { R 5'-ttgtggttgccgcagat-3' }\end{array}$ & 60 & 138 & BC102479.1 \\
\hline 6 & OSTEOCALCIN & $\begin{array}{l}\text { f 5'-cttcgtgtccaagcaggag-3', } \\
\text { r 5'-tccagcggatctgggtag-3', }\end{array}$ & 60 & 99 & AY661470.1 \\
\hline 8 & $\mathrm{CD} 45$ & $\begin{array}{l}\text { f 5'-aaccgetctctcaaccatag-3, } \\
\text { r 5'-tcatcttccacgcagtctac-3', }\end{array}$ & 60 & 288 & AJ400864 \\
\hline
\end{tabular}



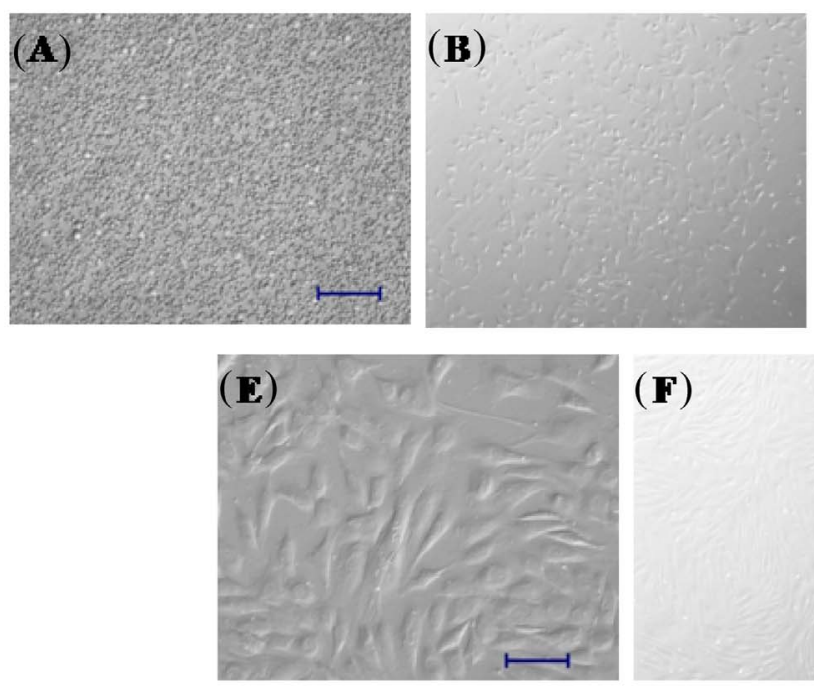
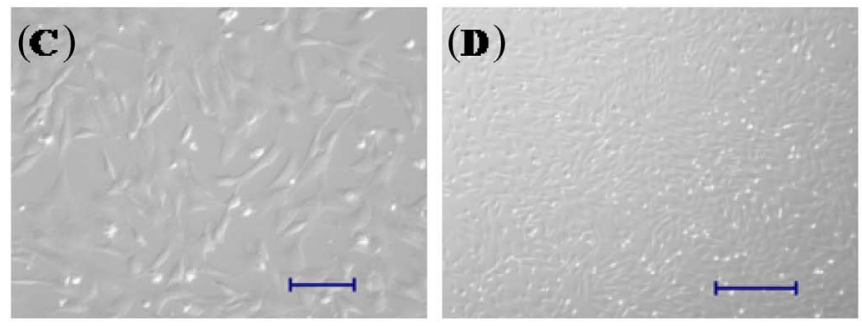

(G)

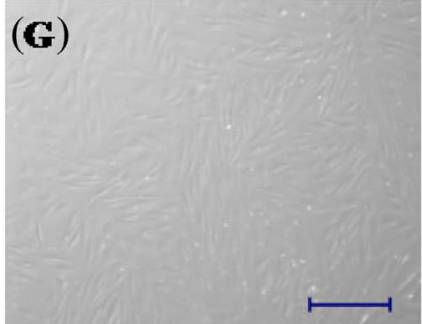

Figure 1. Bone marrow was collected from iliac crest of adult goat and immediately processed for the separation of nucleated cells using density gradient medium by centrifugation method and cells were cultured in DMEM low glucose with FBS and antibiotic. (A) day of culture after centrifugation and proper washing of cells. (B) Cells acquiring the spindle shape on day 6th of culture after frequent change of medium. (C) Day 8th of culture cells are more confluent and showing typical MSC like morphology. (D) On Day 11 th cells are approximately $70 \%-80 \%$ confluent. (E) Cells of passage 5 th showing typical spindle shape. (F) Cells of passage 10 and $(\mathrm{G})$ Cells of passage 15th. Scale bar-(A), (C), \& (E) $200 \mu \mathrm{m}$ and (B), (D), (F) \& (G) $500 \mu \mathrm{m}$.

saline (1X DPBS), and fresh medium was added every 3 - 4 days. The initial adherent cells were observed as triangle or spindle shaped morphology within 5 - 6 days (Figure 1(B)). In 7 - 8 days culture became more confluent (Figure 1(C)), and reached $80 \%-90 \%$ of confluence within 10 - 11 days (Figure 1(D)). In subsequent passages, cBM-MSCs maintained their characteristic spindle-shape (Figure 1(E)), passage 10th (Figure 1(F)). The cells were propagated and brought beyond 15 th passage (Figure 1(G)).

\subsection{Characterisation of cBM-MSCs}

Analysis of transcript abundance of target genes based real time PCR assay showed that under standard culture conditions, cBM-MSCs were found positive for CD105 and CD90 (Figure 2(a)) but negative for haematopoietic cell surface markers like CD45 and CD34 (Figure 2(b)). Furthermore, corresponding cell surface marker proteins were successfully localized in passage four cBM-MSCs monolayer via immunocytochemistry such as CD105 (Figures 3(a)-(c)), CD90 (Figures 3(d)-(f)) and CD73 (Figures 3(g)-(i)). Nucleus was counter stained with DAPI.

\subsection{FACS Analysis}

To verify the cells derived from the caprine bone marrow are mesenchymal stem cells, a panel of antibodies against MSC markers was chosen to evaluate that the cultured cells are MSC. The CD73 and CD105 positive cells were $65.73 \%$ (Figure 4(g)) and $73.29 \%$ (Figures

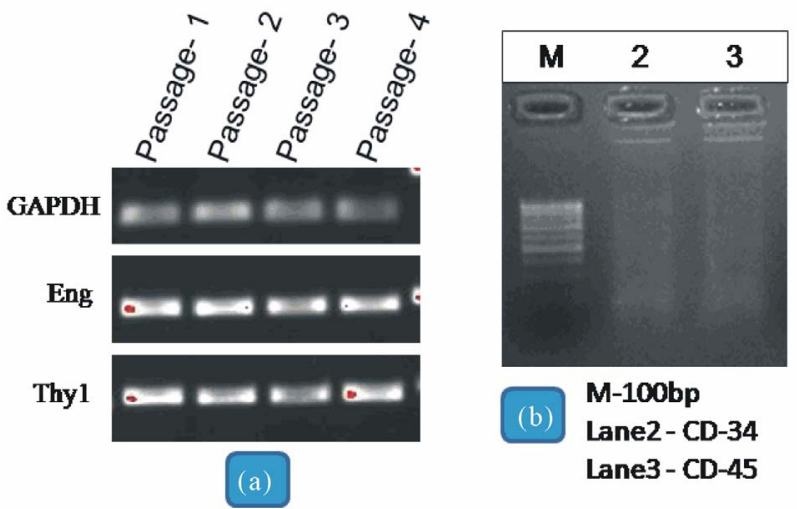

Figure 2. For gene expression analysis, the cultured of different passage were used for checking MSC specific genes by real time PCR. Passage 1 to 4 were used for analysis of Eng (Endoglin) and Thyl and reveled that cells were positive for these markers. Passage fourth cells were also checked for the expression of MSC negative marker CD34 and CD45 and no expression were found in the cultured cells. Gel electrophoresis of PCR amplified products of cBM-MSCs in 2\% agarose gel (a) Showing the house keeping and MSCs specific markers Eng and Thy1. (b) Passage four cells were negative for CD34 and CD45.

4(a) and (b)), respectively and only $0.07 \%$ cells were expressed the CD45 which indicated negative for haemopoietic cells (Figure 4(c)), these results indicate that the cultured cells were MSC.

The cell viability during passaging was checked by FASC analysis after staining by PI stain indicated that around that $92 \%$ cells were healthy and $8 \%$ cells were dead (Figure 4(d)). 


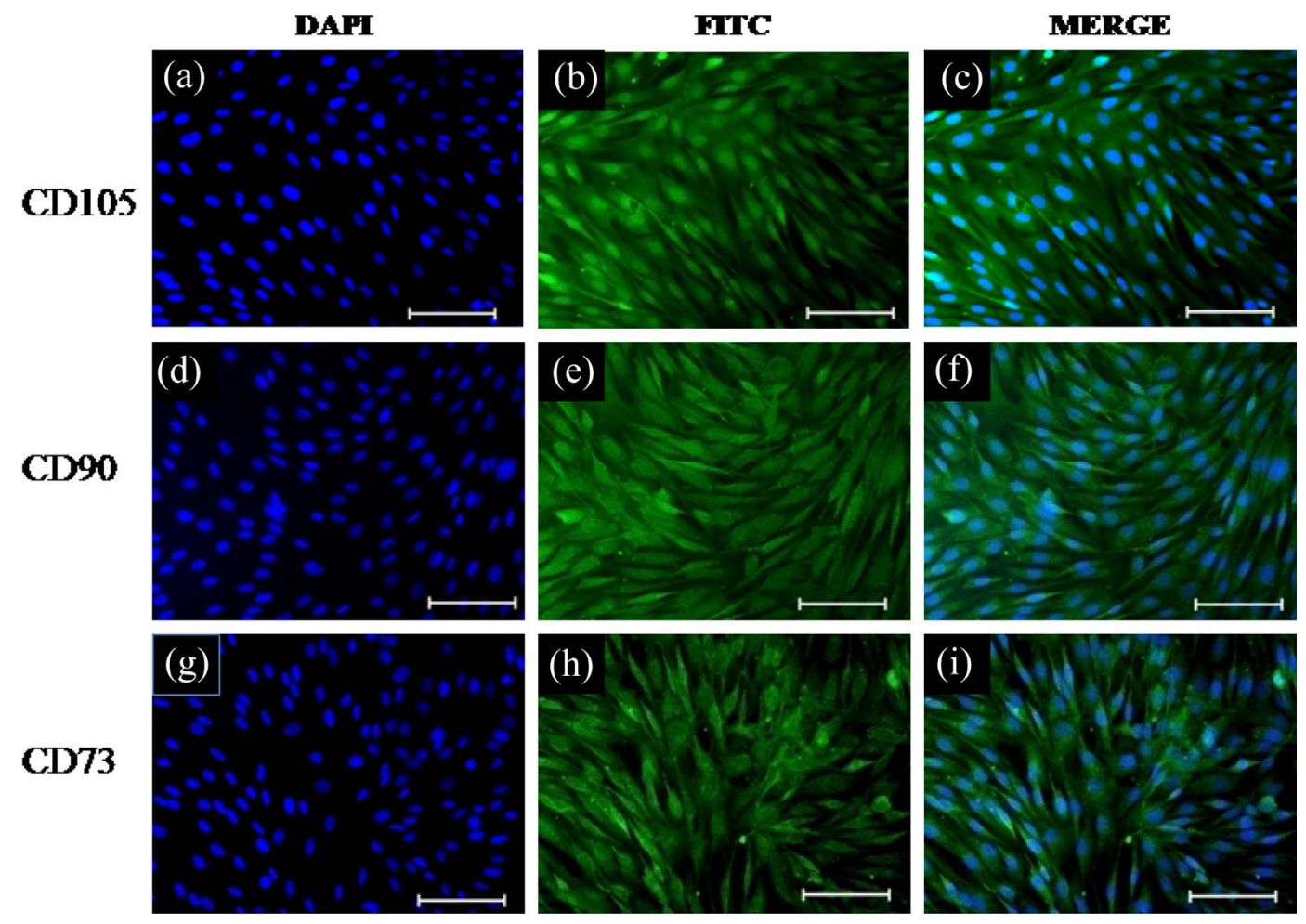

Figure 3. Immunolocalization of surface antigens associated markers in cBM-MSCs monolayer. Cells were stained with primary antibodies directed against CD105 (b), CD90 (e), and CD73 (h), and stained by FITC conjugated secondary antibodies. In alternative panels, (a), (d) \& (g) representative fields of DAPI. In next panels (c), (f), (i) is merger photographs of DAPI and FTTC (Scalebar $=100 \mu \mathrm{m})$.
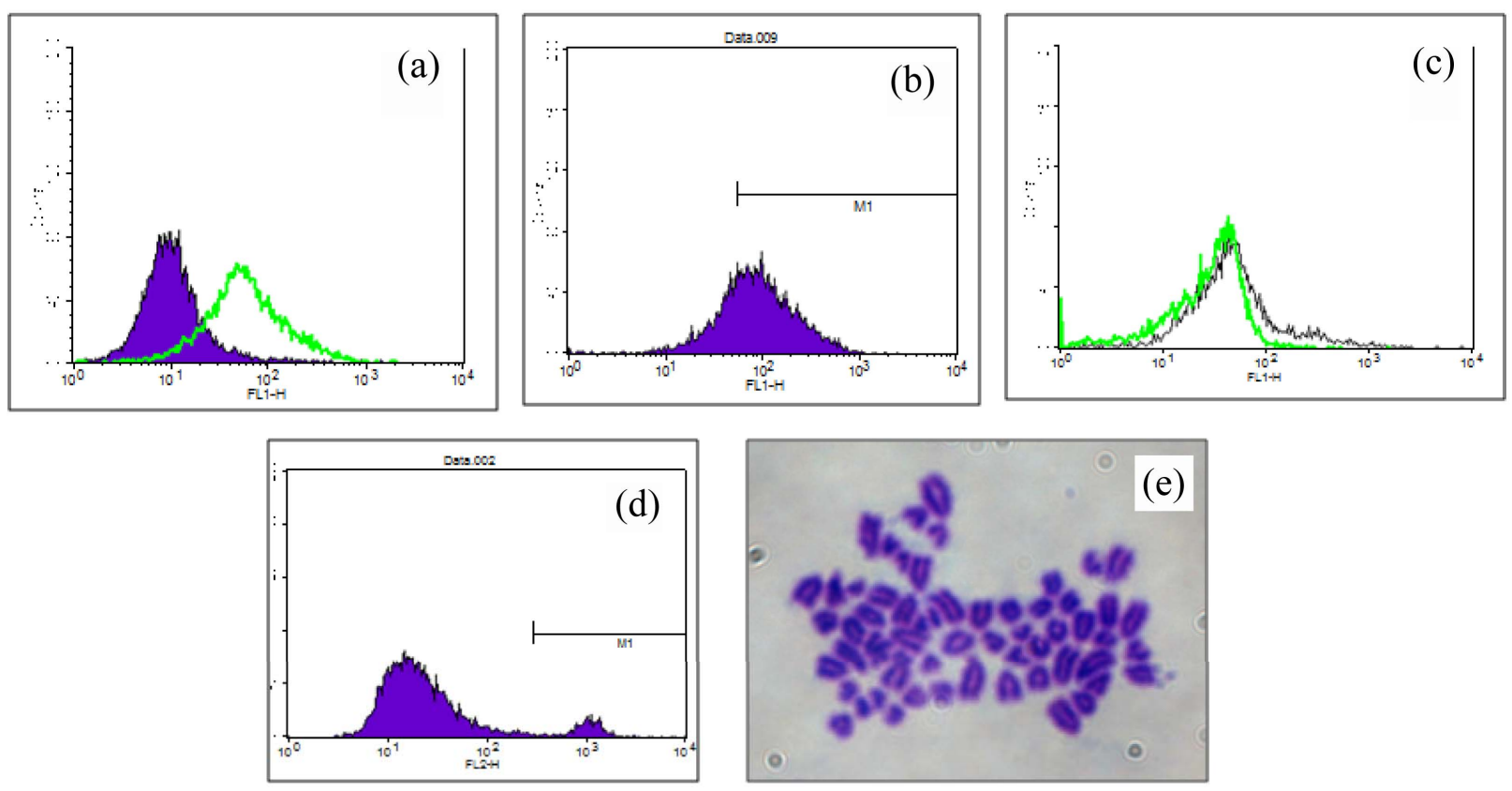

Figure 4. The cultured cBM-MSCs of passage four were used for FACS analysis. MSC specific genes CD73 and CD105 as well as negative marker CD45 were used to ruled out the contamination of other cells. Calibrated histogram representing the number of events in the Y-axis and FTTC-fluorescent intensity (FLH-1) on X-axis. (a) The shadowed histogram indicate $65.73 \%$ positive for CD-73. (b) $73.29 \%$ for CD-105 and (c) CD-45 showed 0.07\%. (d) Passage four cells were used to check the cellular viability and integrity of plasma membrane of cells by FACS analysis after PI staining and $92 \%$ cells were live and around $8 \%$ cells were found dead. (e) cBM-MSCs showed normal chromosomes during in vitro culture. 
Chromosome analysis during in vitro propagation indicated the normal pattern of caprine chromosomes (Figure 4(e)).

\subsection{Multi-Differentiation Potential of cBM-MSCs}

To induce the adipogenesis, after 21 days of co-culture with specific induction media, small lipid droplets appeared within the cytoplasm of cBM-MSCs. Reddish colored lipid droplets could be demonstrated by Oil Red $\mathrm{O}$ staining on $21^{\text {st }}$ day of culture indicative of positive result for primary MSC culture (Figure 5(a)). The control were incubated in normal DMEM culture medium for the same period of time at for the treatment and stained with Oil Red O staining, and showed negative for the presence of lipid droplet (Figure 5(b)).

To induce the osteogenic differentiation, $70 \%-80 \%$ confluence cells was replaced by differentiation medium and cultured for 21 days and media was changed periodically. After 7th - 8th day of co-incubation the cellular aggregates were observed in osteogenic differentiation culture plates and gradually increased till the end of the experiment. These aggregates in culture plate were characterized by calcium deposits, which were demonstrated reddish brownish when stained with Alizarin red stain (Figure 5(c)) as well as alkaline phosphatase staining (Figure 5(e)), control shows no any change after staining (Figure 5(d)). Control was negative for Alizarin red stain which indicated the absence of calcium deposit.

Differentiated cBM-MSCs into adipogenic and osteogenic cells were characterized by molecular methods by real time PCR using osteogenic and adipogenic specific markers. Gel picture of PCR products shows positive for both Osteocalcin and Adipsin (Figure 5(f)) and negative for control.

\subsection{Generation of Transgenic Mesenchymal Stem Cells and Their Characterization}

Once the cBM-MSCs was characterized by molecular method, immunocytochemistry, FACS and in vitro differentiation into other mesenchymal lineage like adipocytes and osteocytes and checked for the normal karyotyping, these cells were used for the generation of transgenic cells. After the establishment of primary culture as MSC, early passage cBM-MSCs were transfected by plasmid vector using lipfectamine as a vehicle in 12 wells plate. After $12 \mathrm{hr}$ of transfection, few cells were started showing GFP expression (Figure 6(a)) and it was increased in subsequent hours (Figure 6(b)), and was stable after $72 \mathrm{hr}$ of transfection (Figures 6(c) and (d)). More than $67 \%$ cells were positive for the GFP expression as observed by FACS analysis (Figure $7(\mathbf{F})$ ). After $72 \mathrm{hr}$, the cells were kept in the selection media contain-

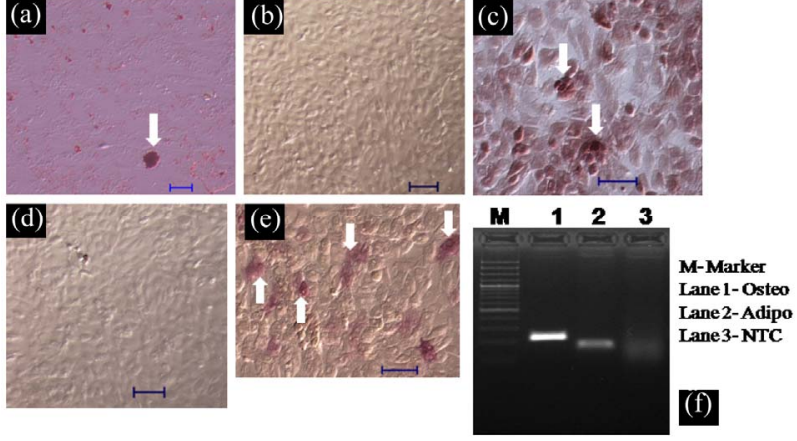

Figure 5. cBM-MSCs were in vitro differentiated into osteocytes and adipocytes. (a) Adipogenesis induced lipid droplets observed in red color after specific Oil Red O staining in in vitro cultured cBM-MSCs (Scale bar $=200 \mu \mathrm{m})$. (b) Control for adipogenic differentiations, absence of lipid droplet. (c) On osteogenic differentiation of cBM-MSCs, brownish colored mineral deposition (arrow) as demonstrated by alizarin red staining (Scale bar $=200 \mu \mathrm{m})$. (d) Control showing negative for the same. (e) Alkaline phosphatase positive cells. (f) In vitro differentiated cBM-MSCs in adipogenic and osteogenic cells were used for molecular characterization using real time PCR. Gel electrophoresis of PCR amplified products of cBM-MSCs in $2 \%$ agarose gel.
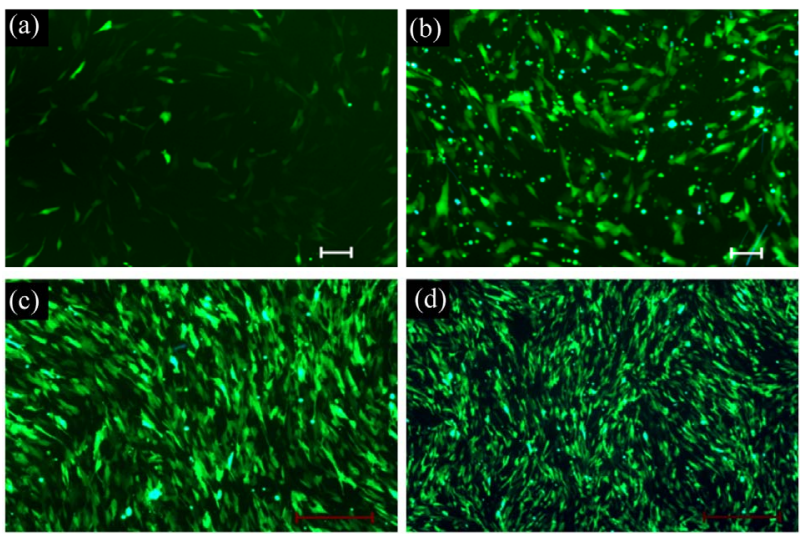

Figure 6. Passage three cBM-MSCs were plated in a 12 -well tissue culture plate $24 \mathrm{hrs}$ before the transfection procedure. DNA/Lipofectamine complex was prepared and adherent cells were washed with FBS and antibiotic free media and complex was added. (a) After $12 \mathrm{hrs}$ of transfection, few cells started showing green colour under fluorescent microscope (Olympus, Japan). (b) $24 \mathrm{hrs}$ of transfection more number of cells were showing the green colour. (c) After $72 \mathrm{hrs}$, large number of cells were expressing the green fluorencence. (d) Green color was stable at $96 \mathrm{hrs}$ indicating continued GFP expression (Scale bar (a) \& (b) $200 \mu \mathrm{m}$, (c) \& (d) $500 \mu \mathrm{m}$ ).

ing $300 \mu \mathrm{g} / \mathrm{ml} \mathrm{G} 418$, and continued in the selection medium. The cells were further passaged and propagated subsequently to increase the cells populations. At passage 3rd, cells were checked for GFP expression and 97\% cells were showing GFP expression under fluorescent microscope. The tcBM-MSCs were successfully propagated beyond 12 th passage by sub culturing them with 

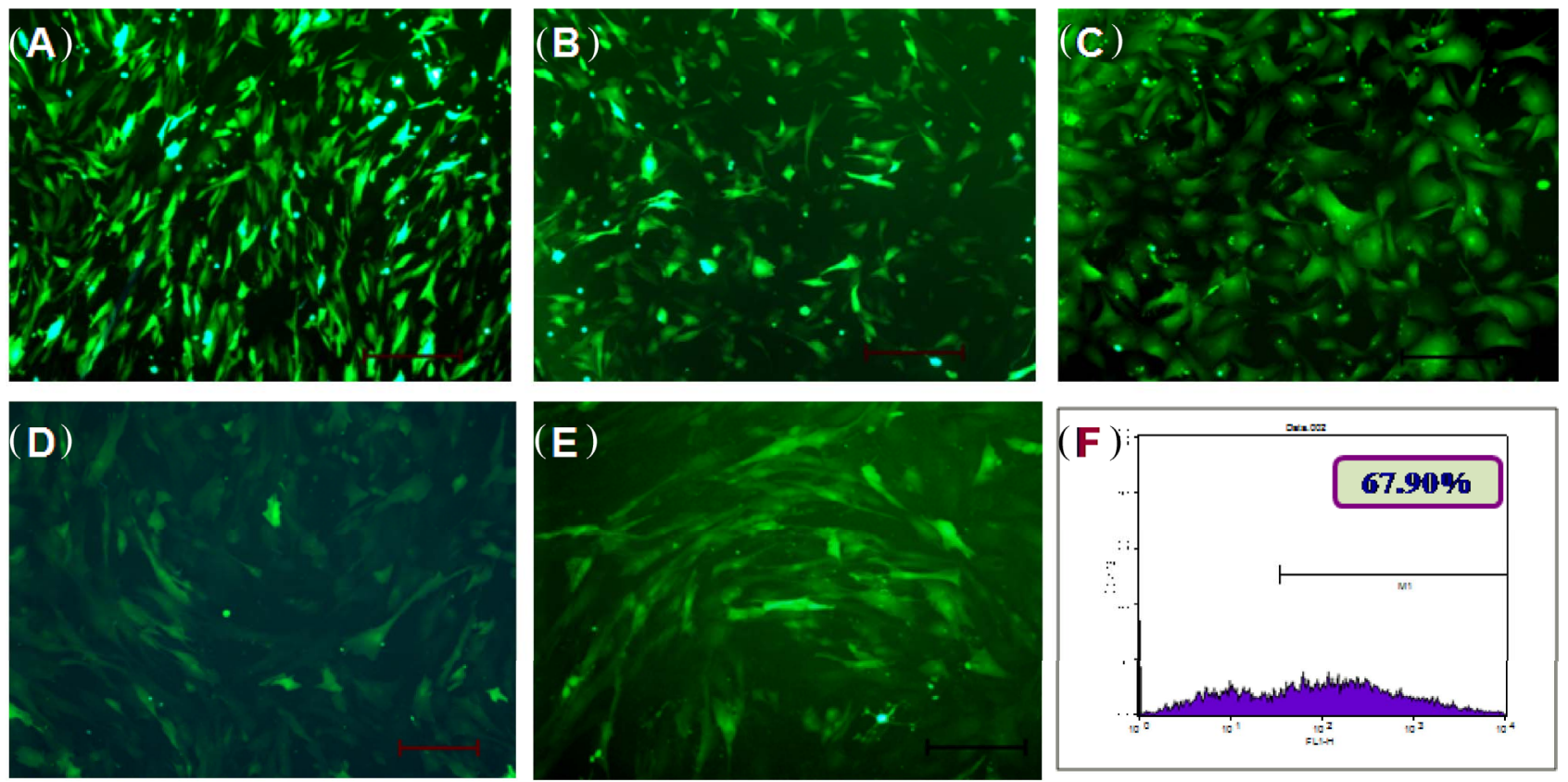

Figure 7. Transgenic cells were passaged and propagated further and reached beyond passage 12th. (A) Passage one cells are showing the green fluorescence. (B) Passage 3rd cells. (C) Passage 5th cells. (D) Passage 8th cells continued showing GFP expression. (E) Passage 10th cells are showing the stable GFP expression. (F) In first passage around $67.9 \%$ cells expressing the GFP when checked by FACS. Scale bar $500 \mu \mathrm{m}$.

trypsinization and the cells were maintaining the GFP expression during different passage (Figure 7). These cells were used for the transplantation studies in rabbit model (data not shown).

To establish that the transfection did not change the MSC characteristics, the tcB-MSCs were further characterized for MSC characteristics. The cell viability of tcB-MSCs checked by FASC analysis indicated that around that $91.45 \%$ cells were healthy and $8.55 \%$ cells were dead (Figure 8(a)). The tcB-MSCs carried normal pattern of caprine chromosomes (Figure 8(b)).

\subsection{Characterization of tcBM-MSCs}

Analysis of transcript abundance of target genes based real time PCR assay showed that under standard culture conditions, transgenic MSCs were found positive for CD73, CD90 and CD105 (Figure 8(c)) and negative for haematopoietic cell surface markers like CD45 and CD34 (Figure 8(d)). Furthermore, corresponding cell surface marker proteins were also successfully localized in tcBM-MSCs monolayer via immunocytochemistry such as CD73, CD90 and CD90 using alexaflour (Figure 9) it showed positive for the above MSC specific markers.

\subsection{Multi-Differentiation Potential of tcBM-MSCs}

The tcBM-MSCs also successfully differentiated into
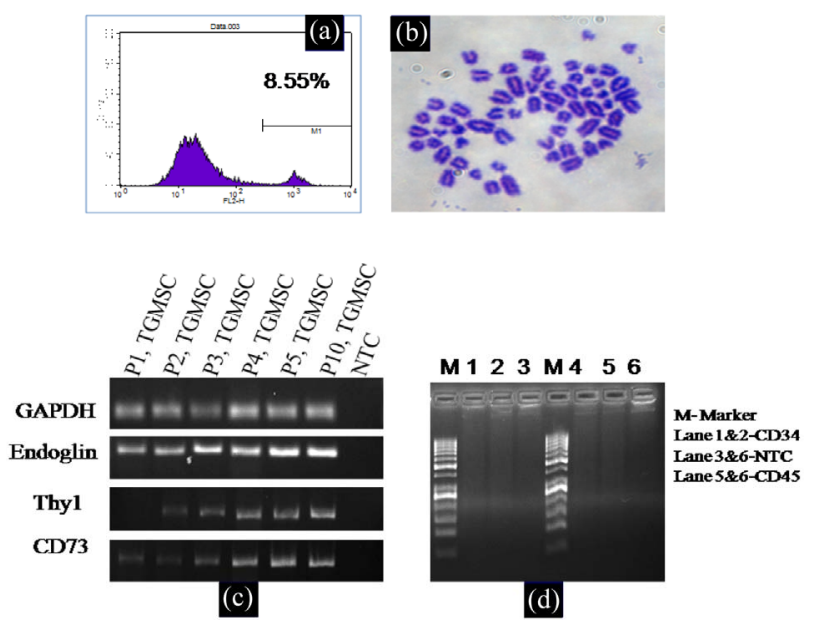

Figure 8. (a) Passage 3rd transgenic cells were used to check the cell viability after PI staining by FACS analysis and around $91.45 \%$ cells live and $8.55 \%$ cells were dead. (b) Passage 3rd transgenic cells were used for chromosome analysis and found the normal chromosomes. For gene expression analysis, these transgenic cells of different passage were used checked for MSC specific genes by real time PCR. Passage 1 to 5 and 10 were used for analysis of Eng. Thyl and CD73 reveled that cells are positive for the specific said markers, passage 2nd cells were also checked for the expression of MSC negative marker including CD34 and CD45 and no expression were found in the cultured cells. Gel electrophoresis of PCR amplified products of transgenic cBM-MSCs in $2 \%$ agarose gel. (c) Showing positive the house keeping and MSCs specific markers endoglin, Thyl and CD73. (d) Passage 2nd cells were negative for CD34 and CD45. 

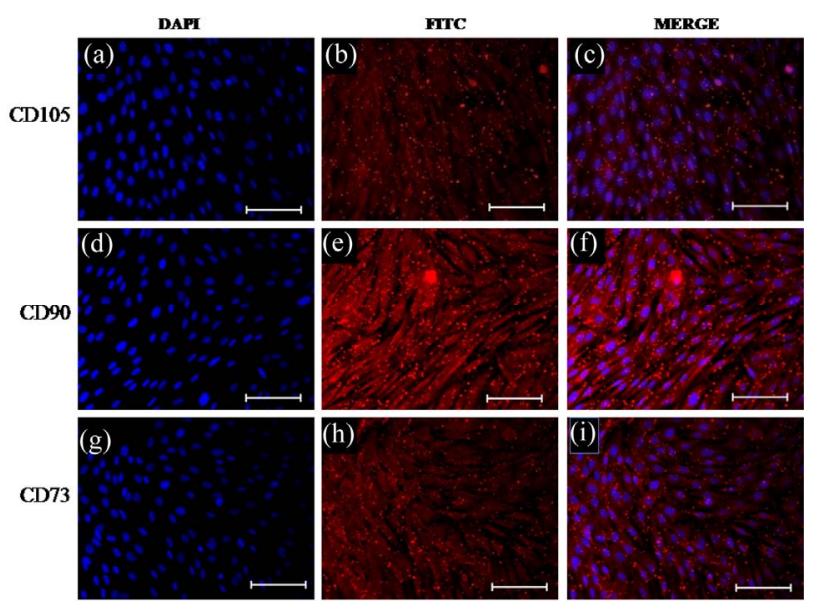

Figure 9. Immunolocalization of surface antigens associated markers in transgenic cBM-MSCs monolayer were done. Cells were stained with primary antibodies directed against CD105 (b), CD90 (e), and CD73 (h), and stained by FITC conjugated secondary antibodies. In alternative panels, (a) (d) and (g) representative fields of DAPI. In next panels (c), (f), (i) is merger photographs of DAPI and FITC (Scalebar $=100 \mu \mathrm{m})$.

adipogenic (Figure 10(a)) as well as osteogenic cells (Figure 10(c)) which was comparable with non transfected MSC cells. Differentiated cBM-MSCs into adipogenic and osteogenic cells were characterized by molecular methods using real time PCR. Gel electrophoresis of PCR products showed positive for Osteocalcin and Adipsin markers (Figure 10(f)).

\subsection{Transdifferentiation of Transgenic MSC into Neurons}

Passage 3rd tcBM-MSCs were used to transdifferentiate into neurons. Initially cells were maintained in sub confluent cultures in serum-containing medium supplemented with $1 \mathrm{mM}$ BME for $24 \mathrm{hr}$ for pre-induction. Cells become rounded in structure after $24 \mathrm{hr}$ of pre-induction (Figure 11(a)). To effect neuronal differentiation, the previous media were replaced by serum-free medium containing 2 - $8 \mathrm{mM}$ BME. Cells were observed $12 \mathrm{hr}$ of exposure to differentiation media, change in morphology of some of the cBM-MSCs were apparent. Responsive cells progressively assumed neuronal morphological characteristics over the first $24 \mathrm{hr}$ of neuronal induction. Initially, cytoplasm in the flat cBM-MSCs retracted towards the nucleus, forming a contracted multipolar, cell body, protruding membranous, process-like extensions peripherally (Figure 11(b)). Over the subsequent hours, cell bodies became increasingly spherical and the cells adopted the morphological features typical of neurons such as refractile cell bodies and long branching processes. Processes continued to elaborate, displaying primary, secondary branches few cells showed tertiary branching also. Even after transdifferentiation of tcBM-MSCs

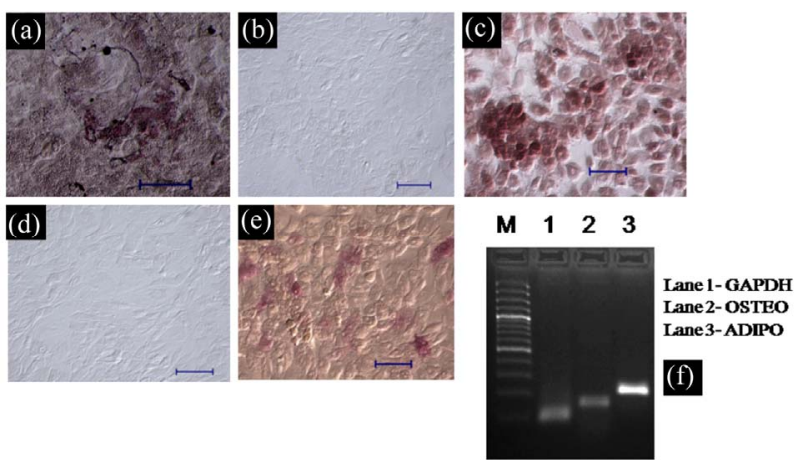

Figure 10. cBM-MSCs were in vitro differentiated into osteocytes and adipocytes. (a) Adipogenesis induced lipid droplets observed in res color after specific Oil Red O staining in in vitro cultured cBM-MSCs (Scale bar $=200 \mu \mathrm{m}$ ). (b) Control for adipogenic differentiations, absence of lipid droplet. (c) On osteogenic differentiation, brownish colored mineral deposition (arrow) were observed as demonstrated by alizarin red staining (Scale bar $=200 \mu \mathrm{m})$. (d) Control showing negative for the alizarin red staining. (e) Alkaline phosphatase positive cells. (f) In vitro differentiated cBM-MSCs in adipogenic and osteogenic cells were used for molecular characterization using real time PCR. Gel electrophoresis of PCR amplified products of cBMMSCs in 2\% agarose gel.
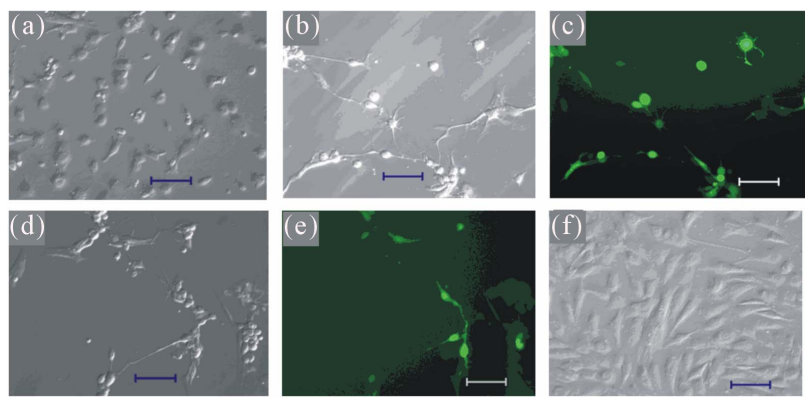

Figure 11. Neuronal differentiation of transgenic cBM-MSCs, passage four cells were used for the transdifferentiation into neurons. (a) After $24 \mathrm{hrs}$ of pre-induction, cytoplasm were retracted toward nucleus and cBM-MSCs became rounded in structure. (b) Cytoplasm retracted towards the nucleus, forming a contracted multipolar, cell body, protruding membranous, process-like extensions peripherally. (c) fluorescent photographs of same field taken under. The neuronal differentiation protocol was initiated once the cells were sub confluent.

expressing the GFP under fluorescent microscope which indicate the stable transfection of the cBM-MSC (Figures 11(c) and (e)). Control was run simultaneously and no change in morphology of cells was observed (Figure 11(f)).

\section{DISCUSSION}

Mesenchymal stem cells show great promises as a biological therapeutic for a diverse range of unmet medical needs. The reasons for this are many and include, ease of isolation and expansion in culture, multipotency, paracrine effects, immunomodulatory properties, migratory 
behavior and ethical considerations. Though the bone marrow may be the preferred homing organ for MSCs injected intravenously in the normal untroubled animal [26-28], but this is not the case when inflammation is present in the animal, in this condition MSC appear to preferentially home to the site of inflammation when injected intravenously [29,30]. MSC may demonstrate plasticity beyond their traditional mesodermal lineage, in that they have been induced to generate, in vitro at least, into tissues of both ectodermal (neurons) and endodermal (hepatocytes) nature $[31,32]$. In addition, their ease and reproducibility of isolation, high expansion potential and capacity for useful modification using molecular biological engineering techniques, make them good candidates for the repair and regeneration of a large variety of tissues. They have been shown in preclinical studies to improve many incurable disease including myocardial function, cerebral function, liver damage and joint damage [33-38]. MSC appear to have a major advantage over many other cell types for cellular therapy, in that they are immunologically privileged and in large out bred animals can generally be transplanted across MHC barriers without the need for immunosuppression [39]. This has important implications for the therapeutic application of MSC [40].

The present study was carried out to isolate caprine MSC from bone marrow and generation of transgenic MSC using plasmid based vector for their future use in cell based therapeutics and transgenic animal production. The present study was focused with isolation of MSC from caprine bone marrow and generation of transgenic MSC using plasmid based vector. We had successfully isolated caprine MSC showing typical mesenchymal fibroblastic phenotypes (Figure 1) which were similar to the other reports $[41,42]$. The isolated cBM-MSCs were positive for CD90 and CD105 and negative for CD45 and CD34 (Figure 3), suggesting that the established cBM-MSCs were not from hematopoietic lineages [4346]. We also demonstrated through differentiation studies that cBM-MSCs have the potentials to differentiate into adipogenic and osteogenic cell lineages (Figures 5(a) and (c)) as was observed by other researcher [47] who reported that murine MSCs can be differentiated into several specialized mesodermal cell types like bone, tendon, cartilage, musle and heart.

The production of cells capable of expressing gene(s) of interest is important for a variety of applications in biomedicine and biotechnology, including gene therapy and a novel method of stem cells therapy in the various diseases. Achieving high levels of transgene expression for the longer period of time, without adversely affecting cell viability and differentiation capacity of the cells, is crucial. Tracking of cells after transplantation into the animal is necessary to check the ability of MSC in regeneration of particular tissue. It will enhance the im- portance of stem cells therapy in the treatment of incurable disease. A variety of studies using vectors based on oncogenic retroviruses have been attempted to transduce MSCs, but there have been problems due to a number of issues. A major limitation of transduction approaches involving oncogenic retroviral vectors such as Moloney murine leukaemia virus (MoMLV) is a general lack of long-term transgene expression [48,49], possibly due to the inactivation of the retroviral long terminal repeat vectors based on murine stem cell virus appear to be less prone to transcriptional silencing of viral gene expression and, thus, appear to be more promising. Transduction of MSCs with MoMLV and murine stem cell virus-based vectors were shown to be inefficient, as they required drug selection to enrich transduced cells [49,50], multiple rounds of transduction for several days [51-53], or highly concentrated vector stocks [54]. To bypass safety concerns associated with viral vectors and other instrument handling, alternative, non-viral based methods for trans gene delivery were established for MSCs. Unfortunately, traditional transfection methods have shown little success in delivering plasmid DNA into primary MSCs, usually resulting in low transfection efficiencies and high cell mortality.

In the present experiment, the plasmid vector pAcGFP1-C1 was chosen to transfect the cBM-MSCs and we generated the stable transgenic caprine bone marrow MSCs (tcBM-MSCs). In primary culture of transfected cells around 67\% was expressing GFP (Figure 7(F)) and after antibiotic selection about $97 \%$ cells were showing GFP expression at third passage (Figure 2). The tcBMMSCs were successfully propagated beyond twelfth passage (P12) and the cells showed robust GFP expression throughout the passages. One group of researcher [55] reported that by plasmid, transfected MSC have shown high viabilities $(>90 \%)$ and recoveries $(>52 \%)$ while maintaining their multipotency, this might be an advantageous transfection strategy when the goal is to express a therapeutic gene in a safe and transient way.

To verify that the transgenic cells retained typical MSC characters following transfection, the tcBM-MSCs cells were checked for expression of MSC specific genes by different methods and found positive for the expression of MSC specific genes CD73, CD90 and CD105 by imuunostaining as well as RTPCR, and negative for CD45 and CD34. The tcBM-MSCs were also readily differentiated into adipocytes and osteocytes. Present study suggested that the tcBM-MSCs had the similar characteristics and potential as normal MSC. Present results are accordance with the other reports [56] where they have demonstrated that Using Lentiviral vector, they were able to show specific stable suppression of eGFP expression in MSCs and hESCs with no alteration in the ability of the transduced cells to [56]. 
Presently, the widely used method to transfer genes to MSC is performed through defective viruses, such as adenovirus, lentivirus, and retrovirus [57]. When MSCs are used to compensate or correct a genetic pathology and must express the therapeutic gene for the duration of a patient's life (permanent expression), integrating viruses, such as lentivirus or retrovirus, are preferred because of their well-known capacity for long-term expression. On the contrary, when MSCs are used to treat noninherited diseases and are only required to express the therapeutic gene for a short period of time (transient expression), nonintegrating vectors including adenoviruses and nonviral gene delivery systems are preferred [58]. Recent results from several labs have indicated that HIV-1-based vectors are very efficient at delivering and expressing transgenes into MSCs [21,23,59]. A single round of transduction using unconcentrated HIV-1-based lentiviral vectors led to the efficient transduction of human MSCs and sustained transgene expression for up to at least 5 months [20]. An advantage of lentiviral vectors over vectors based on oncogenic retroviruses is that they are capable of transducing non-dividing cells [60]. One researchor [61] described a method for efficiently transducing murine MSC using lentiviral vectors. In case of adenoviral vectors, transgene delivery by unmodified adenoviral (Ad) vectors appears to be inefficient as far as MSCs are concerned. Some researcher [62] have used Ad vectors to deliver reporter genes into ex vivo expanded MPCs. Only $19 \%$ of the cells expressed the transgene, possibly due to the absence of the corresponding Coxsackie adenovirus receptor receptor on such cells [63].

Although viral vectors permit efficient transgene delivery, but safety concerns associated with viral transduction have prompted a search for alternative non-viral gene delivery methods [56]. Unfortunately, traditional transfection methods have shown little success in delivering plasmid DNA into primary MSCs, usually resulting in low transfection efficiencies and high cell mortality. Development of a novel, noninvasive transgene delivery protocol, based on the principle of electric field-induced molecular vibration [64]. This promising procedure did not interfere with the normal cellular differentiation activities of human and chick mesenchymal progenitors. In a recent report [65] described liposome-based transfection methods to introduce transgenes and small interfering RNAs (siRNAs) into human MSCs. Transfected MSC maintained their proliferation capacity paired with the ability to differentiate into different mesodermal lineages (bone, cartilage and fat) without loss of transgene expression. Transfection efficiencies ranged from $2 \%$ to $35 \%$, resulting from using a Lipid/DNA ratio of 1.25 with a transgene expression of 7 days [56]. Stable transfection of plasmid DNA into rat MSCs by electroporation was successful [66].
To verify that the transgenic cells retained typical MSC characters following transfection the tcBM-MSCs cells were further characterized. The transgenic MSC were expressing MSC specific genes CD73, CD90 and CD105 (Figure 8(c)) and were negative for CD45 and CD34 (Figures 8(d) and 9(a)-(i)). Further, these cells also retained the capacity to differentiate into adipocytes, osteoblasts and neuronal cells (Figures 10(a) and (c)).

\section{CONCLUSION}

In the present study MSC has been isolated and characterized from bone marrow and a transgenic MSC is generated with stable GFP expression in caprine using plasmid vector. It was also observed that the transgenic MSC retained all the MSC characteristrtics as well as differentiation potentiality including neurons allowing these cells for application in cell therapy with tracking ability. To the best of our knowledge this is the first report in domestic animals to generate transgenic MSCs using non-viral vector.

\section{ACKNOWLEDGEMENTS}

Authors are thankful to Director, Indian Veterinary Research Institute (IVRI) and NAIP, ICAR for providing necessary financial assistance and support for completing this work.

\section{REFERENCES}

[1] Pittenger, M.F., Mackay, A.M., Beck, S.C., Jaiswal, R.K., Douglas, R., Mosca, J.D., Moorman, M.A., Simonetti, D.W., Craig, S. and Marshak, D.R. (1999) Multilineage potential of adult human mesenchymal stem cells. Science, 284, 143-147.

http://dx.doi.org/10.1126/science.284.5411.143

[2] Caplan, A.I. (2007) Adult mesenchymal stem cells for tissue engineering versus regenerative medicine. Journal of Cell Physiology, 213, 341-347.

http://dx.doi.org/10.1002/jep.21200

[3] Makino, S., Fukuda, K., Miyoshi, S., Konishi, F., Kodama, H., Pan, J., Sano, M., Takahashi, T., Hori, S., Abe, H., Hata, J., Umezawa, A. and Ogawa, S. (1999) Cardiomyocytes can be generated from marrow stromal cells in vitro. Journal of Clinical Investigation, 103, 697-705. http://dx.doi.org/10.1172/JCI5298

[4] Kopen, G.C., Prockop, D.J. and Phinney, D.G. (1999) Marrow stromal cells migrate throughout forebrain and cerebellum, and they differentiate into astrocytes after injection into neonatal mouse brains. Proceedings of the National Academy of Sciences of the United States of America, 96, 10711-10716. http://dx.doi.org/10.1073/pnas.96.19.10711

[5] Barry, F.P. and Murphy, J.M. (2004) Mesenchymal stem cells, clinical applications and biological characterization. International Journal of Biochemical and Cell Biology, 36, 568-584

http://dx.doi.org/10.1016/j.biocel.2003.11.001 
[6] Mahmood, A., Lu, D., Lu, M. and Chopp, M. (2003) Treatment of traumatic brain injury in adult rats with intravenous administration of human bone marrow stromal cells. Neurosurgery, 53, 697-702.

http://dx.doi.org/10.1227/01.NEU.0000079333.61863.AA

[7] Ryan, J.M., Barry, F., Murphy, J.M. and Mahon, B.P. (2007) Interferon-gamma does not break, but promotes the immunosuppressive capacity of adult human mesenchymal stem cells. Clinical Experimental Immunology, 149, 353-363. http://dx.doi.org/10.1111/j.1365-2249.2007.03422.x

[8] Kumar, S., Chanda, D. and Ponnazhagan, S. (2008) Therapeutic potential of genetically modified mesenchymal stem cells. Gene Therapy, 15, 711-715. http://dx.doi.org/10.1038/gt.2008.35

[9] Orlic, D., Kajstura, J., Chimenti, S., Limana, F., Jakoniuk, I. and Quaini, F. (2001) Mobilized bone marrow cells repair the infarcted heart, improving function and survival. Proceedings of the National Academy of Sciences of the United States of America, 98, 10344. http://dx.doi.org/10.1073/pnas.181177898

[10] Hibi, H., Yamada, Y. and Kagami, H. (2006) Distraction osteogenesis assisted by tissue engineering in an irradiated mandible, a case report. International Journal of Oral Maxillofac Implants, 21, 141.

[11] Yoshikawa, T., Mitsuno, H., Nonaka, I., Sen, Y., Kawanishi, K., Inada, Y., Takakura, Y., Okuchi, K. and Nonomura, A. (2008) Wound therapy by marrow mesenchymal cell transplantation. Plastic and Reconstructive Surgery, 121, 860 . http://dx.doi.org/10.1097/01.prs.0000299922.96006.24

[12] Sasaki, M., Abe, R., Fujita, Y., Ando, S., Inokuma, D. and Shimizu, H. (2008) Mesenchymal stem cells are recruited into wounded skin and contribute to wound repair by transdifferentiation into multiple skin cell type. Journal of Immunology, 180, 2581.

[13] Ringden, O., Uzunel, M., Rasmusson, I., Remberger, M., Sundberg, B., Lonnies, H. Marschall, H.U., Dlugosz, A., Szakos, A., Hassan, Z., Omazic, B., Aschan, J., Barkholt, L. and Le Blanc, K. (2006) Mesenchymal stem cells for treatment of therapy-resistant graftversus-host disease. Transplantation, 81, 1390-1397. http://dx.doi.org/10.1097/01.tp.0000214462.63943.14

[14] Amado, L.C., Saliaris, A.P., Schuleri, K.H., St John, M., Xie, J.S., Cattaneo, S., Durand, D.J., Fitton, T., Kuang, J.Q., Stewart, G., Lehrke, S., Baumgartner, W.W., Martin, B.J., Heldman, A.W. and Hare, J.M. (2005) Cardiac repair with intramyocardial injection of allogeneic mesenchymal stem cells after myocardial infarction. Proceedings of the National Academy of Sciences of the United States of America, 102, 11474-11479.

http://dx.doi.org/10.1073/pnas.0504388102

[15] McDonald, J.W. and Becker, D. (2003) Spinal cord injury, promising interventions and realistic goals. American Journal of Physical Medicine \& Rehabilitation, 82, 38. http://dx.doi.org/10.1097/01.PHM.0000086994.53716.17

[16] Reiss, K., Mentlein, R., Sievers, J. and Hartmann, D. (2002) Stromal cell-derived factor 1 is secreted by meningeal cells and acts as chemotactic factor on neuronal stem cells of the cerebellar external granular layer. $\mathrm{Neu}$ - roscience, 115, 295.

http://dx.doi.org/10.1016/S0306-4522(02)00307-X

[17] Okabe, M., Ikawa, M., Kominami, K., Nakanishi, T. and Nishimune, Y. (1997) "Green mice" as a source of ubiquitous green cells. FEBS, 407, 313 . http://dx.doi.org/10.1016/S0014-5793(97)00313-X

[18] McMahon, J.M., Conroy, S., Lyons, M., Greiser, U., O'shea, C., Strappe, P., Howard, L., Murphy, M., Barry, F. and O'brien, T. (2006) Gene transfer into rat mesenchymal stem cells, a comparative study of viral and nonviral vectors. Stem Cells and Development, 15, 87. http://dx.doi.org/10.1089/scd.2006.15.87

[19] McGinley, L., McMahon, J., Strappe, P., Barry, F., Murphy, M., O'Toole, D. and O'Brien1, T. (2011) Lentiviral vector mediated modification of mesenchymal stem cells and enhanced survival in an in vitro model of ischaemia. Stem Cell Research and Therapy, 12, 1-18.

[20] Zhang, X.Y., La Russa, V.F., Bao, L., Kolls, J., Schwarzenberger, P. and Reiser, J. (2002) Lentiviral vectors for sustained transgene expression in human bone marrowderived stromal cells. Molecular Therapy, 5, 555-565. http://dx.doi.org/10.1006/mthe.2002.0585

[21] Totsugawa, T., Kobayashi, N., Okitsu, T., Noguchi, H., Watanabe, T., Matsumura, T., Maruyama, M., Fujiwara, T., Sakaguchi, M. and Tanaka, N. (2002) Lentiviral transfer of the LacZ gene into human endothelial cells and human bone marrow mesenchymal stem cells. Cell Transplantation, 11, 481-488.

[22] Davis, B.M., Humeau, L., Slepushkin, V., Binder, G., Korshalla, L., Ni, Y., Ogunjimi, E.O., Chang, L.F., Lu, X. and Dropulic, B. (2004) ABC transporter inhibitors that are substrates enhance lentiviral vector transduction into primitive haematopoietic progenitor cells. Blood, 104, 364-373. http://dx.doi.org/10.1182/blood-2003-07-2363

[23] Chan, J., O'donoghue, K., de la Fuente, J., Roberts, I.A., Kumar, S., Morgan, E.J. and Fisk, M.N. (2005) Human fetal mesenchymal stem cells as vehicles for gene delivery. Stem Cells, 23, 93-102. http://dx.doi.org/10.1634/stemcells.2004-0138

[24] Kumar, M., Yasotha, T., Singh, R.K., Singh, R., Kumar, K., Ranjan, R., Chetan, D., Das, B.C. and Bag, S. (2013) Generation of transgenic mesenchymal stem cells expressing GFP as reporter gene using no viral vector in caprine. Indian Journal of Experimental Biology, 51, 502509.

[25] Woodbury, D., Reynolds, K. and Black, I.B. (2002) Adult bone marrow stromal stem cells express germline, ectodermal, endodermal, and mesodermal genes prior to neurogenesis. Journal of Neuroscience Research, 96, 908917. http://dx.doi.org/10.1002/jnr.10365

[26] Wynn, R.F., Hart, C.A., Corradi-Perini, C., O’Neill, L., Evans, C.A., Wraith, J.E., Fairbairn, L.J. and Bellantuono, I. (2004) A small proportion of mesenchymal stem cells strongly expresses functionally active CXCR4 receptor capable of promoting migration to bone marrow. Blood, 104, 2643-2645. http://dx.doi.org/10.1182/blood-2004-02-0526

[27] Devine, S.M., Bartholomew, A.M., Mahmud, N., Nelson, M., Patil, S., Hardy, W., Sturgeon, C., Hewett, T., Chung, 
T., Stock, W., Sher, D., Weissman, S., Ferrer, K., Mosca, J., Deans, R., Moseley, A. and Hoffman, R. (2001) Mesenchymal stem cells are capable of homing to the bone marrow of non-human primates following systemic infusion. Experimental Hematology, 29, 244-255. http://dx.doi.org/10.1016/S0301-472X(00)00635-4

[28] Bensidhoum, M., Chapel, A., Francois, A., Demarquay, C., Mazurier, C., Fouillard, L., Bouchet, S., Bertho, J.M., Gourmelon, P., Aigueperse, J., Charbord, P., Gorin, N.C., Thierry, D. and Lopez, M. (2004) Homing of in vitro expanded Stro-1- or Stro-1+ human mesenchymal stem cells into the NOD/SCID mouse and their role in supporting human CD34 cell engraftment. Blood, 103, 33133319. http://dx.doi.org/10.1182/blood-2003-04-1121

[29] Chapel, A., Bertho, J.M., Bensidhoum, M., Fouillard, L., Young, R.G., Frick, J., Demarquay, C., Cuvelier, F., Mathieu, E., Trompier, F., Dudoignon, N., Germain, C., Mazurier, C., Aigueperse, J., Borneman, J., Gorin, N.C., Gourmelon, P. and Thierry, D. (2003) Mesenchymal stem cells home to injured tissues when co-infused with hematopoietic cells to treat a radiation-induced multi-organ failure syndrome. Journal of Gene Medicine, 5, 10281038. http://dx.doi.org/10.1002/jgm.452

[30] Ortiz, L.A., Gambelli, F., McBride, C., Gaupp, D., Baddoo, M. and Kaminski, N. (2003) Mesenchymal stem cell engraftment in lung is enhanced in response to bleomycin exposure and ameliorates its fibrotic effects. Proceedings of the National Academy of Sciences of the United States of America, 100, 8407-8411. http://dx.doi.org/10.1073/pnas.1432929100

[31] Lee, C.I., Kohn, D.B., Ekert, J.E. and Tarantal, A.F. (2004) Morphological analysis and lentiviral transduction of fetal monkey bone marrow-derived mesenchymal stem cells. Molecular Therapy, 9, 112-123. http://dx.doi.org/10.1016/j.ymthe.2003.09.019

[32] Jiang, Y., Jahagirdar, B.N., Reinhardt, R.L., Schwartz, R.E., Keene, C.D., Ortiz-Gonzalez, X.R., Reyes, M., Lenvik, T., Lund, T., Blackstad, M., Du, J., Aldrich, S., Lisberg, A., Low, W.C., Largaespada, D.A. and Verfaillie, C.M. (2002) Pluripotency of mesenchymal stem cells derived from adult marrow. Nature, 418, 41-49. http://dx.doi.org/10.1038/nature00870

[33] Deans, R.J. and Moseley, A.B. (2000) Mesenchymal stem cells, biology and potential clinical uses. Experimental Hematology, 28, 875-884. http://dx.doi.org/10.1016/S0301-472X(00)00482-3

[34] Itescu, S., Schuster, M.D. and Kocher, A.A. (2003) New directions in strategies using cell therapy for heart disease. Journal of Molecular Medicine, 81, 288-296.

[35] Toma, C., Pittenger, M.F., Cahill, K.S., Byrne, B.J. and Kessler, P.D. (2002) Human mesenchymal stem cells differentiate to a cardiomyocyte phenotype in the adult murine heart. Circulation, 105, 93-98. http://dx.doi.org/10.1161/hc0102.101442

[36] Fang, B., Shi, M., Liao, L., Yang, S., Liu, Y. and Zhao, R.C. (2004) Systemic infusion of FLK1(+) mesenchymal stem cells ameliorate carbon tetrachloride induced liver fibrosis in mice. Transplantation, 78, 83-88. http://dx.doi.org/10.1097/01.TP.0000128326.95294.14

[37] Murphy, J.M., Fink, D.J., Hunziker, E.B. and Barry, F.P.
(2003) Stem cell therapy in a caprine model of osteoarthritis. Arthritis Rheuminent, 48, 3464-3474. http://dx.doi.org/10.1002/art.11365

[38] Orlic, D., Kajstura, J., Chimenti, S., Jakoniuk, I., Anderson, S.M., Li, B., Pickel, J., McKay, R., Nadal-Ginard, B., David, M., Bodine, D.M., Leri, A. and Anversa, P. (2001) Bone marrow cells regenerate infarcted myocardium. Nature, 410, 701-705. http://dx.doi.org/10.1038/35070587

[39] Devine, S.M., Cobbs, C., Jennings, M., Bartholomew, A. and Hoffman, R. (2003) Mesenchymal stem cells distribute to a wide range of tissues following systemic infusion into nonhuman primates. Blood, 101, 2999-3001. http://dx.doi.org/10.1182/blood-2002-06-1830

[40] Sordi, V., Malosio, M.L., Marchesi, F., Mercalli, A., Melzi, R., Giordano, T., Belmonte, N., Ferrari, G., Leone, B.E., Bertuzzi, F., Zerbini, G., Allavena, P., Bonifacio, E. and Piemonti, L. (2005) Bone marrow mesenchymal stem cells express a restricted set of functionally active chemo kine receptors capable of promoting migration to pancreatic islets. Blood, 106, 419-427.

http://dx.doi.org/10.1182/blood-2004-09-3507

[41] Simmons, P.J. and Torok-Storb, B. (1991) Identification of stromal cell precursors in human bone marrow by a novel monoclonal antbody-STRO-1. Blood, 78, 55-62.

[42] Rosada, C., Justesen, J., Melsvik, D., Ebbesen, P. and Kassem, M. (2003) The human umbilical cord blood, a potential source for osteoblast progenitor cells. Calcif Tissue International, 72, 135-142.

http://dx.doi.org/10.1007/s00223-002-2002-9

[43] Haynesworth, S.E., Goshima, J., Goldberg, W.M. and Caplan, A.I. (1992) Characterization of cells with osteogenic potential from human marrow. Bone, 13, 81-88. http://dx.doi.org/10.1016/8756-3282(92)90364-3

[44] Sacchetti, B., Funari, A., Michienzi, S., Di Cesare, S., Piersanti, S., Saggio, I., Tagliafico, E., Ferrari, S., Robey, P.G., Riminucci, M. and Bianco, P. (2007) Self-renewing osteoprogenitors in bone marrow sinusoids can organize a hematopoietic microenvironment. Cell, 131, 324-336. http://dx.doi.org/10.1016/j.cell.2007.08.025

[45] Kassem, M., Kristiansen, M. and Abdallah, B.M. (2004) Mesenchymal stem cells, cell biology and potential use in therapy. Basic Clinical, Pharmacology and Toxicology, 95, 209-214. http://dx.doi.org/10.1111/j.1742-7843.2004.pto950502.x

[46] Krabbe, C., Zimmer, J. and Meyer, M. (2005) Neural transdifferentiation of mesenchymal stem cells - A critical review. APMIS, 113, 831-844. http://dx.doi.org/10.1111/j.1600-0463.2005.apm_3061.x

[47] Woodbury, D., Reynolds, K. and Black, I.B. (2002). Adult bone marrow stromal stem cells express germline, ectodermal, endodermal, and mesodermal genes prior to neurogenesis. Journal of Neuroscience Research, 69, 908917. http://dx.doi.org/10.1002/jnr.10365

[48] Chuah, M.K., Van Damme, A., Zwinnen, H., Goovaerts, I., Vanslembrouck, V., Collen, D. and VandenDriessche, T. (2000) Long-term persistence of human bone marrow stromal cells transduced with Factor VIII-retroviral vectors and transient production of therapeutic levels of hu- 
man Factor VIII in nonmyeloablated immunodeficient mice. Human Gene Therapy, 11, 729-738. http://dx.doi.org/10.1089/10430340050015626

[49] Schwarz, E.J., Alexander, G.M., Prockop, D.J. and Azizi, S.A. (1999) Multipotential marrow stromal cells transduced to produce L-DOPA, engraftment in a rat model of Parkinson's disease. Human Gene Therapy, 10, 25392549. http://dx.doi.org/10.1089/10430349950016870

[50] Allay, J.A., Dennis, J.E., Haynesworth, S.E., Majumdar, M.K., Clapp, D.W., Shultz, L.D., Caplan, A.I. and Gerson, S.L. (1997) Lacz and interleukin-3 expression in vivo after retroviral transduction of marrow-derived human osteogenic mesenchymal progenitors. Human Gene Therapy, 8, 1417-1427. http://dx.doi.org/10.1089/hum.1997.8.12-1417

[51] Marx, J.C., Allay, J.A., Persons, D.A., Nooner, S.A., Hargrove, P.W., Kelly, P.F., Vanin, E.F. and Horwitz, E.M. (1999) High-efficiency transduction and long-term gene expression with a murine stem cell retroviral vector encoding the green fluorescent protein in human marrow stromal cells. Human Gene Therapy, 10, 1163-1173. http://dx.doi.org/10.1089/10430349950018157

[52] Chianget, G.G., Rubin, H.I., Cherington, V., Wang, T., Sobolewski, J., McGrath, C.A., Gaffney, A., Emami, S., Sarver, N., Levine, P.H., Greenberger, J.S. and Hurwitz, D.R. (1999) Bone marrow stromal cell-mediated gene therapy for hemophilia $\mathrm{A}$, in vitro expression of human Factor VIII with high biological activity requires the inclusion of the proteolytic site at amino acid 1648. Human Gene Therapy, 10, 61-76.

http://dx.doi.org/10.1089/10430349950019192

[53] Chuah, M.K., Brems, H., Vanslembrouck, V., Collen, D. and Vandendriessche, T. (1998) Bone marrow stromal cells as targets for gene therapy of hemophilia A. Human Gene Therapy, 9, 353-365. http://dx.doi.org/10.1089/hum.1998.9.3-353

[54] Jaalouk, D.E., Eliopoulos, N., Couture, C., Mader, S. and Galipeau, J. (2000) Glucocorticoid-inducible retrovector for regulated transgene expression in genetically engineered bone marrow stromal cells. Human Gene Therapy, 11, 1837-1849. http://dx.doi.org/10.1089/10430340050129468

[55] Madeira, C., Mendes, R.D., Ribeiro, S.C., Boura, J.S., Aires-Barros, M.R., da Silva, C.L., and Cabral, J.M.S. (2010) Nonviral gene delivery to mesenchymal stem cells using cationic liposomes for gene and cell therapy. Journal of Biomedicine and Biotechnology, 12, 1-12. http://dx.doi.org/10.1155/2010/735349

[56] Clements, M.O., Godfrey, A., Crossley, J., Wilson, S.J., Takeuchi, Y. and Boshoff, C. (2006) Lentiviral manipulation of gene expression in human adult and embryonic stem cell. Tissue Engineering, 12, 7-13. http://dx.doi.org/10.1089/ten.2006.12.1741
[57] Zhang, X. and Godbey, W.T. (2006) Viral vectors for gene delivery in tissue engineering. Advance Drug Delivery Reviews, 58, 515-534. http://dx.doi.org/10.1016/j.addr.2006.03.006

[58] Park, S.J. and Na, K. (2012) The transfection efficiency of photo sensitizer-induced gene delivery to human MSCs and internalization rates of eGFP and Runx2 genes. Biomaterials, 33, 6485-6494. http://dx.doi.org/10.1016/j.biomaterials.2012.05.040

[59] Devis, B.M., Humeau, L. and Slepushkin, V. (2004) ABC transporter inhibitors that are substrates enhance lentiviral vector transduction into primitive haematopoietic progenitor cells. Blood, 104, 364-373. http://dx.doi.org/10.1182/blood-2003-07-2363

[60] Reiser, J., Harmison, G., Kluepfel-Stahl, S., Brady, R.O., Karlsson, S. and Schubert, M. (1996) Transduction of nondividing cells using pseudotyped defective high-titer HIV Type 1 particles. Proceedings of the National Academy of Sciences of the United States of America, 93, 15266-15271. http://dx.doi.org/10.1073/pnas.93.26.15266

[61] Anjos-Alfonso, F., Siapati, E.K. and Bonnet, D. (2004) In vivo contribution of murine mesenchymal stem cells into multiple cell-types under minimal damage conditions. Journal of Cell Science, 117, 5655-5664. http://dx.doi.org/10.1242/jcs.01488

[62] Conget, P.A. and Minguell, J.J. (2000) Adenoviral-mediated gene transfer into ex vivo expanded human bone marrow mesenchymal progenitor cells. Experimental Hematology, 28, 382-390.

http://dx.doi.org/10.1016/S0301-472X(00)00134-X

[63] Hung, S.C., Lu, C.Y., Shyue, S.K., Liu, H.C. and Ho, L.L. (2004) Lineage differentiation-associated loss of adenoviral susceptibility and Coxsackie-adenovirus receptor expression in human mesenchymal stem cells. Stem Cells, 22, 1321-1329. http://dx.doi.org/10.1634/stemcells.2003-0176

[64] Song, L., Webb, N.E., Song, Y. and Tuan, R.S. (2006) Identification and functional analysis of candidate genes regulating mesenchymal stem cells self-renewal and multipotency. Stem Cells, 24, 1707-1718. http://dx.doi.org/10.1634/stemcells.2005-0604

[65] Hoelters, J., Ciccarella, M., Drechsel, M., Geissler, C., Gülkan, H., Böcker, W., Schieker, M., Jochum, M. and Neth, P. (2005) Nonviral genetic modification mediates effective transgene expression and functional RNA interference in human mesenchymal stem cells. Journal of Gene Medicine, 7, 718-728. http://dx.doi.org/10.1002/jgm.731

[66] Peister, A., Mellad, J.A., Wang, M., Tucker, H.A. and Prockop, D.J. (2004) Stable transfection of MSCs by electroporation. Gene Therapy, 11, 224-228. http://dx.doi.org/10.1038/sj.gt.3302163 